\title{
$\sin$
}

Revista Educación

ISSN: 0379-7082

ISSN: 2215-2644

revedu@gmail.com

Universidad de Costa Rica

Costa Rica

\section{How English as a Foreign Language (EFL) University Students Understand the Pronunciation of Adjectives Ending in -ed}

Charpentier Jiménez, William

How English as a Foreign Language (EFL) University Students Understand the Pronunciation of Adjectives Ending in -ed

Revista Educación, vol. 44, no. 1, 2020

Universidad de Costa Rica, Costa Rica

Available in: http://www.redalyc.org/articulo.oa?id=44060092025

DOI: https://doi.org/10.15517/revedu.v44i1.36052

Esta obra está bajo una Licencia Creative Commons Atribución-NoComercial-SinDerivar 3.0 Internacional. 


\title{
How English as a Foreign Language (EFL) University Students Understand the Pronunciation of Adjectives Ending in -ed
}

\author{
Comprensión de la pronunciación de adjetivos terminados en -ed por parte de estudiantes universitarios del inglés \\ como idioma extranjero
}

William Charpentier Jiménez

Universidad de Costa Rica, Costa Rica

william.charpentier@ucr.ac.cr

iD http://orcid.org/0000-0002-8554-7819

\author{
DOI: https://doi.org/10.15517/revedu.v44i1.36052 \\ Redalyc: http://www.redalyc.org/articulo.oa?id=44060092025
}

Received: 17 May 2019

Accepted: 18 November 2019

\begin{abstract}
:
This article looks at how EFL university students understand the pronunciation of adjectives that end in -ed. The goal is to determine the extent to which students are able to follow pronunciation rules and exceptions of -ed inflections when used as adjectives. The quantitative study presents data gathered from a 20 -item multiple choice test that was taken by 61 students. Overall results reveal that students obtained low scores $(M=7.33, S D=1.51, n=61)$ and even lower scores $(M=2.00, S D=2.33, n=$ 61 for non-governed-rule -ed endings) with regards to following rule-governed pronunciation patterns. On average, students were able to identify -ed endings pronounced /\#d/ 8.2\% of the times, followed by /d/ (7.31\%) and / $\mathrm{t} /(6.49 \%)$. Students scored lowest for non-standard pronunciation of participial adjectives $(2.72 \%)$. The results reveal that students have not yet mastered the rules for the pronunciation of participial adjectives ending in -ed. The author proposes that changes be made to the curriculum and the design of the materials and that current classroom practices be assessed in order to help improve student pronunciation. Lastly, the author highlights the need to conduct further research focusing on pronunciation and auditory perception to attain this goal. KEYWORDS: Spoken Language, Speech Education, Language Instruction, Higher Education.
\end{abstract}

\section{ReSUMEN:}

Este artículo analiza la comprensión de los estudiantes universitarios del inglés como segundo idioma con respecto a las reglas de pronunciación de adjetivos en inglés que finalizan en -ed. El objetivo es determinar la medida en que los estudiantes pueden seguir tanto las reglas de pronunciación como las excepciones de las inflexiones que finalizan en -ed cuando dichas palabras se utilizan como adjetivos. Este estudio cuantitativo presenta datos recopilados de una prueba de escogencia múltiple de 20 preguntas. Un total de 61 participantes realizó la prueba. Los resultados generales muestran que los estudiantes obtuvieron notas bajas $(\mathrm{M}=7.33$, $\mathrm{SD}=1.51, \mathrm{n}=61$ para adjetivos que terminan en -ed que representan una excepción a la regla) con respecto al seguimiento de patrones de pronunciación con reglas establecidas. En promedio, los estudiantes lograron pronunciar los adjetivos que finalizan con -ed correctamente como /\#d/, el 8,2\% de las veces, seguido por /d/ (7.31\%) and /t/ (6.49\%). Los estudiantes obtuvieron la puntación más baja con respecto a la pronunciación atípica de los adjetivos participios. El autor propone realizar cambios al currículum y el diseño de los materiales además de evaluar prácticas actuales en el aula con el fin de mejorar la pronunciación del estudiante. Por último, el autor enfatiza la necesidad de realizar más estudios enfocados en la pronunciación y percepción auditiva para alcanzar dicha meta.

Palabras Clave: Lengua hablada, Educación de la expresión oral, Enseñanza de idiomas, Educación superior.

\section{INTRODUCTION}

For most non-native speakers, English pronunciation is a difficult aspect to master. Compared to other languages, English does not greatly adhere to phonemic orthographic conventions. However, other languages such as Italian, Turkish, or Spanish have more consistent orthographic systems or phonemic representations. Therefore, adults learning a second language tend to pay close attention to the rules that govern the language they are studying. English as a Second Language often concentrate on grammar and punctuation rules, 
while leaving spelling and pronunciation rules in second place. This trend is understandable since, as was previously stated, phonemic orthography present in English is not very reliable in terms of rule formation. Some rules, however, have become an essential component of language programs. In terms of pronunciation, the inflectional endings (especially the -s and -ed inflectional endings) have reached a privileged status and are considered mandatory in the language curriculum. Although inflectional endings are not phonemic, they predominantly follow pronunciation patterns or rules that learners can rely on. Nonetheless, ignoring or overgeneralizing these rules often lead to communication problems between learners of English as a second language and English native speakers.

The purpose of this investigation was to explore university ESL students' understanding of -ed adjective pronunciation. Although most -ed adjectives come from regular past participles of verbs and maintain their same pronunciation, some part-of-speech alternations exist. Celce-Murcia, Brinton, and Goodwin (2016) explain that there are "historically based differences in pronunciation between certain forms ending in -ed, depending on whether they function as adjectives or verbs" (p. 411). When students consistently mispronounce certain words incorrectly, especially if these words are frequently used in the target language, a potential for communication breakdown exists. As mentioned before, the academic curriculum includes rules for the pronunciation of -ed endings; however, little research has been conducted to investigate the pronunciation of -ed inflections used as adjectives or used as adjectives in part-of-speech alternations. Therefore, the guiding objectives of the present study are to measure students' understanding of -ed adjective pronunciation in general and to measure students' understanding of -ed adjective pronunciation in part-ofspeech alternations. Based on the results, this paper also seeks to propose some curricular changes that could help improve students' awareness of -ed adjective pronunciation.

Analyzing student pronunciation is vital to promote educational reforms that aim at improving understanding and production of the language. A study of this nature may reveal if students are overgeneralizing or ignoring rules they have studied, thus causing pronunciation errors during oral production. Two main groups may take advantage of this study. On the one hand, professors would have a better idea of what students have understood in terms of -ed endings and their corresponding pronunciation. This, in turn, would allow professors to modify their teaching practices and propose curricular reforms to improve the curriculum. On the other hand, students would have a better understanding of their performance. This will help them raise awareness about the correct pronunciation of -ed inflections and their exceptions to the rules. Students would also benefit from any curricular change or teaching practice derived from this project.

Speaking is one of the most essential skills in language-learning and pronunciation helps convey the message in an intelligible and comprehensible manner. Certain rules in English pronunciation may be difficult to internalize for second language learners, a process that demands considerable effort when considering exceptions to these rules. The pronunciation of -ed inflections use as verbs is part of virtually all language programs and course books. Nevertheless, the pronunciation of -ed inflections working as adjectives has often been overlooked or has not been fully studied, particularly when part-of-speech alternations affect pronunciation. Measuring student understanding of those rules would certainly be useful for keeping or modifying teaching practices and curricular contents and objectives in the language program.

This paper is divided into six sections. The introduction describes the importance of gaining insight as to how well students understand the pronunciation of -ed endings with regards to the objectives of this study. This literature review addresses many of the main concepts related to pronunciation and describes previous related research. The methods section specifies the study design and describes the participants, materials, and produces used. The results report on data collection and recruitment (response rates, etc.) and presents key findings with respect to the central research question. The discussion section states the main findings of the study. The conclusion discusses the main results with reference to previous research and offers perspectives for future work and recommendations based on the results. 


\section{Literature RevieW}

To better understand -ed inflectional endings used as adjectives, some definitions are helpful at the outset. Regular past tense endings are among the most studied rules in the field of linguistics and applied linguistics (Celce-Murcia et al., 2016; Kolln and Funk, 2011; Akmajian, Demers, Farmer, and Harnish, 2010). CelceMurcia et al (2016) provide three basic rules for the pronunciation of the -ed inflectional ending:

1. When the verb ends in $/ \mathrm{d} /$ or $/ \mathrm{t} /$, the ending takes an epenthetic (i.e., extra) vowel and is presented as $/ \# \mathrm{~d} /$ or $/ \mathrm{ad} /$.

2 . When the verb ends in a voiced sound other than $/ \mathrm{d} /$, the ending undergoes progressive assimilation and is pronounced as $/ \mathrm{d} /$.

3. When the verb ends in a voiceless consonant other than $/ t /$, the ending also undergoes progressive assimilation and is pronounced as /t/ (p.399).

Roach (2010) explains that assimilation refers to the influence neighboring sounds have on a given sound. Progressive assimilation occurs when a sound influences the following sound, as opposed to regressive assimilation, i.e., when a sound influences one which precedes it. In the case of -ed inflections, this assimilation represents an allomorphic variation. Kolln and Funk (2011) define an allomorph as a variation of a morpheme, usually determined by its environment. Additionally, Plag (2003) states that "it is the sound structure that conditions the distribution of the allomorphs, i.e., determines which allomorph has to be used in a given linguistic context. This is called phonological conditioning" (p. 35). Another environmental feature that may be difficult for students is voicing. Richards and Schmidt (2010) explain that "speech sounds which are produced with the vocal cords vibrating are called voiced. Speech sounds which are produced without vibration of the vocal cords are called voiceless" (p. 630). For students, many times, this linguistic context makes no sense as they try to extrapolate the known set of rules from their L1 to the rules of the L2. At other times, they generalize learned rules to linguistic contexts as exceptions to the rules.

In English, -ed inflectional endings do not function as adjectives. Kolln and Funk (2011) explain that it is the actual -en verb (or verb phrase) that functions as an adjective or adverb. Nevertheless, regular -en verbs do not change form and follow the same aforementioned pronunciation rules of -ed inflectional endings. As the authors explain, this functional shift is just the conversion of one word class to another simply by changing its function but not necessarily its structure or pronunciation. According to Celce-Murcia et al. (2016) although -ed inflections are used as verb or adjectival markers, most of them follow the previously outlined pronunciation rules outlined. However, the authors emphasize that certain -ed words vary depending on whether they are used as adjectives or verbs, such as "-ed adjectives which have an extra syllable and adhere to an /\#d/ pronunciation, as opposed to verbs that simply take /t/ or /d/ which follow the rules of the regular past tense and past participle...when there is an adjective with no corresponding verb” (p. 411). For example, words such as naked, rugged, wretched, and wicked are -ed ending adjectives that do not have a verb counterpart with the -ed ending as /\#d/. The pronunciation of the -ed ending may vary not based on the part of speech it belongs to but on the meaning the word has. For example, the word learned would be pronounced with a final / d/ sound when meaning attainment of knowledge or a skill (e.g., a learned language), but would be pronounced as /\#d/ when describing an intellectual or scholarly individual (e.g., a learned scholar). These differences in pronunciation between -ed inflections may confuse students when assimilating the rules.

Although certain pronunciation features have been widely studied, very little research has been done on the pronunciation of -ed adjective inflections, especially those that follow irregular pronunciation patterns. Bassetti and Atkinson (2015) state that "in spite of burgeoning evidence that the orthographic forms (spellings) of second language (L2) words affect L2 learners' pronunciation, little is known about the pronunciation of known words in experienced learners" (p. 67). Their research included 15 Italian nativespeaking, high-school learners of English who had been taking English lessons for more than 11 years. Their study sought to investigate four "orthographic effects on the pronunciation of L2 English words in instructed learners" (p. 67). The researchers focused on the pronunciation of silent letters, vowel spelling, and vowel 
duration, the pronunciation of the past tense inflection -ed, and the production of homophonic words. In relation to the inflectional -ed markers, the researchers used 21 regular verbs with different realizations of the -ed inflection. In addition, the list included 6 irregular verbs as control variables. To collect data, students were recorded while reading a list of the verbs that contained the base form. Students were instructed to state the base form and produce the simple past, past participle, and third person singular form of each verb. Results show that students often confused -ed realized as $/ \mathrm{t} /$ with $/ \mathrm{d} /$ or $/ \# \mathrm{~d} /$ more than $80 \%$ of the times. For verbs that should end in $/ d /$, students tended to confuse them with $/ t /$ in, approximately, $75 \%$ of the samples, while -ed inflections realized as /\#d/ were correctly pronounced $95 \%$ of the times. Results confirmed that students' production of -ed inflected verbs is quite limited, despite the number of years spent in learning the target language.

Davila (2013) also explored the pronunciation of the -ed inflection in a study which included 48 native Spanish speakers who were learning English as a Foreign Language (ESL). The students were classified according to three levels: High Beginner, Intermediate, and High Intermediate. The objective of the study was "to examine if the accurate pronunciation of the three allomorphs of the -ed ending improves with the level of English" (p. 15) and to determine "which of the three phonological realizations of the English past tense inflectional morpheme -ed is the most mispronounced" (p. 15). Participants were asked to complete a survey in order to collect demographic data. A list of 44 isolated regular past tense verbs was also used. Each student was asked to read the list of verbs and recorded "to measure the three phonological realizations of the -ed inflectional morpheme, 4 for /ad, \#d/, 12 for /t/, and 28 for /d/" (p. 17). Two major findings were identified. Overall, no significant differences were found in terms of proficiency level. Despite their level of English, all students tended to make mistakes when pronouncing -ed endings. Second, students struggled more with one type of pronunciation compared to students at other levels. For example, high beginners had more trouble pronouncing -ed inflections pronounced as $/ \mathrm{t} /$ ( $87 \%$ rate error) and $/ \mathrm{d} /$ (69\% rate error). Intermediate students, were particularly challenged with -ed inflections pronounced as $/ \mathrm{t} /$ ( $42 \%$ rate error) and high intermediate students faced more difficulties, although in a lesser degree, with /\# $\mathrm{d} /$ ( $23 \%$ error rate). This study reflects that pronouncing-ed inflections is challenging for students at all levels. On the other hand, it also proves that reforms need to be made in order to improve students' production of past tense, regular inflections.

In addition to analysis of student perception and production of -ed inflections, studies have acknowledged that pronouncing-ed endings poses a challenge to EFL students. Two studies in particular explore practical and long-term solutions to address this. Caballero and Rosado (2018) investigated the extent to which groups taught through neuro-linguistic programming techniques versus standard techniques compared in terms of their progress in pronouncing regular verbs in the past tense. For data collection purposes, students were asked to record a text containing 10 regular verbs in the past prior to the intervention. After the intervention, students were asked to record a text containing 8 regular verbs in the past. Students were also asked to record their spontaneous answers to questions that elicited the use of regular verbs in the past. In the pre-instruction phase, results show that standard groups obtained $74 \%$ correct answers while the NLP group obtained 50\% correct answers. After the intervention, the NLP group surpassed the standard group by $23.7 \%$ in the first activity (NLP group $=76.1 \%$ success rate, standard group $=52.4 \%$ success rate). In the second activity, results were very similar. When answering spontaneously, the NLP group surpassed the standard group by $24.6 \%$ (NLP group $=70.4 \%$ success rate, standard group $=45.8 \%$ success rate). The general results show that although both groups showed improvement, the NLP group had the biggest increase rate (preinstruction $=50 \%$ success rate, post-instruction $=80 \%$ success rate) while the standard group showed a slight improvement (pre-instruction $=74 \%$ success rate, post-instruction $=84 \%$ success rate). Although it is worth noticing that the NLP group had an initial score lower than the standard group, results reveal considerable progress in pronouncing -ed inflection. Activities and techniques such as those developed by Caballero and Rosado (2018) should also be considered when promoting curricular changes guided by research results. 
A second study on improving student pronunciation of -ed inflections was conducted by Cardoso (2018). Using a text-to-speech synthesizer (TTS), the project aimed to determine if TTS-based instruction was better than instruction led by a language teacher for the acquisition of the simple past -ed when speaking. In this study, 18 intermediate EFL students were divided into two groups. The first group completed a word reading activity and a guided task using a TTS application while the second group completed the same activities assisted by a language teacher. In general terms, results indicated that $/ \# \mathrm{~d} /$ is the easiest realization for students to produce followed by $/ \mathrm{d} / \mathrm{and} / \mathrm{t} /$. In terms of improvement, the researcher mentions that both groups "behaved similarly regarding the production of RPT (regular past tense): while they both improved in producing $/ \mathrm{d} /$, there was no significant improvement in their production of $/ \# \mathrm{~d} /$ (participants scored at the ceiling level on the pretest) and /t/" (p. 20). Taking into account the results presented by Cardoso (2018), researchers should start integrating various techniques, including newer technological devices and applications, to foster a more dynamic understanding of students' acquisition of inflectional morphemes in general and the -ed inflection in particular.

Research on -ed inflections reveals how demanding it is for students to produce and understand the morphemic variations of said inflection. As a whole, research shows that across proficiency levels, students struggle more with / $\mathrm{t} /$ endings, followed by /d/ endings. The realization /\#d/ seems to be the easiest one for students to recognize and produce. On the other hand, some research has dealt with ways to improve pronunciation through teaching practices. NLP- and TTS-based instruction have been used, with various degrees of success, to tackle the pervasive mispronunciation of -ed inflections. However, it should be noted that research findings on past inflections do not fully account for the objectives of the present study. Although the pronunciation of the participial -en and the past -ed markers are the same, some participial en structures used as adjectives do not follow the pronunciation rules described before. No paper dedicated to those differences was found, and thus the importance of a study of this nature in the EFL context is highlighted.

To examine to what extent students have mastered the pronunciation of -ed adjectives in English, the following research question was posed: How aware are EFL students of the pronunciation of regular and irregular -ed adjectives in English? In order to answer this question, this paper uses descriptive statistics. Data was analyzed using measures of spread.

\section{Method}

\section{1. Participants}

This study included 61 students taking a second-year, oral course from the English major. This oral course emphasizes the pronunciation of segmental features or the language. Students are required to transcribe words and phrases to the International Phonetic Alphabet, explain the theory that governs the pronunciation of individual sounds, and describe the pronunciation rules present in the English language. All participants studied English as a foreign language in an EFL environment. They were chosen since they have already taken specific contents related to the -ed inflection and have studied the rules that govern the pronunciation of this inflection. A total of 67 students were invited to participate; however, in the end, 6 students decided not to participate ( $91.04 \%$ participation rate).

\section{2. Materials}

A printed, written consent was created and distributed to invite students to participate. This consent was also sent to students electronically. In order to avoid "extralinguistic knowledge, such as background knowledge, 
and linguistic knowledge, including discourse knowledge, speech act knowledge, and knowledge of grammar, vocabulary, and phonology" (Thornbury, 2005, p. 26) from interfering with the results, a printed, multiplechoice test was developed to obtain information about students' understanding of -ed adjectives with rulegoverned pronunciation and their corresponding exceptions. A copy of the test can be found at the end of this document (See Appendix A). To test reliability, two instruments, both measuring the same variables and relating (or correlating) the scores for the same group of individuals to the two instruments were used. The first version of the test was pilot-tested with fifteen students with a similar affiliation as the target population. It was later revised on the basis of the pilot-testing.

The test contained 20 multiple choice items. For each item, students had to read a sentence and choose the corresponding pronunciation $(/ \mathrm{t} /, / \mathrm{d} /$, or $/ \# \mathrm{~d} /)$ of an underlined word. All words were participle adjectivals with an -ed suffix. Some of these words followed standard -ed inflection pronunciation rules $(\mathrm{n}=15: / \mathrm{t} /$ $=5, / \mathrm{d} /=5, / \# \mathrm{~d} /=5)$, while others $(\mathrm{n}=5)$ clearly were exceptions to the rules. Although the number of words with exceptions seems small, the total number of words in the English language that follow this nonstandard pattern is also small. Materials did not ask students to pronounce or listen to the words with -ed endings. The purpose of the test was to gather information about what students know about the rules and exceptions of -ed endings.

\section{3. Procedure}

This study used a quantitative study design. The researcher requested permission to attend three classes and ask students for their participation. After describing the purpose of the study, students were given a written consent. The researcher instructed them to read it, ask any questions they deemed necessary, and sign it if they wished to participate. After collecting all the consents, a total of 61 participants took the test. Individually, students were given time to read the test and choose the answers according to their knowledge of pronunciation rules. Since students are familiar with the symbols $/ \mathrm{t} /, / \mathrm{d} /$, or $/ \# \mathrm{~d} /$, these same symbols were employed in the test. No student asked any question about the procedure or the contents of the test. All information collected was anonymous; however, students were asked to write their university ID in case they later opted out of participating in the research project.

\section{Analysis of the Results}

The following analysis of the results presents five types of data. The first corresponds to the results of the test in its entirety and combines NRG (non-rule-governed) participles with RG (rule-governed) participles. A separate analysis will be conducted to measure student scores regarding NRG participles only. The third group of data shows results for RG participles only. The fourth offers a comparison between morphemes / $\mathrm{t} /, / \mathrm{d} /, / \# \mathrm{~d} /$ and the non-standard pronunciation of participial adjectives ending in -ed. The fifth compares those NRG participles considered to be most difficult for students.

Figure 1 contrasts the results of the entire text, thus revealing that student performance is rather low (M $=6.18, \mathrm{SD}=1.13, \mathrm{n}=61)$. Based on the results, only half of the population ( $3^{\text {rd }}$ and $4^{\text {th }}$ quartiles) would obtain the minimum grade to pass the test. But, although the maximum grade was a 9 out of 10 , two outliers display results of 2.5 and 3. On the other hand, the lowest results considered NRGs $(\mathrm{M}=2.00, \mathrm{SD}=2.33$, $\mathrm{n}=61$ ) only. Students in the $1^{\text {st }}, 2^{\text {nd, }} 3^{\text {rd }}$ and even the $4^{\text {th }}$ quartile did not attain a minimum score of 7 . The threshold score stands at 8 while 18 students had no correct answers $(\mathrm{Mo}=0)$. When considering account rule-governed participles, results show some improvement $(M=7.33, S D=1.51, n=61)$. In this case, students in the $2^{\text {nd }}, 3^{\text {rd }}$ and $4^{\text {th }}$ quartiles would be able to pass the test. The scores range from a maximum of 10 to an outlier of 3.33 . 


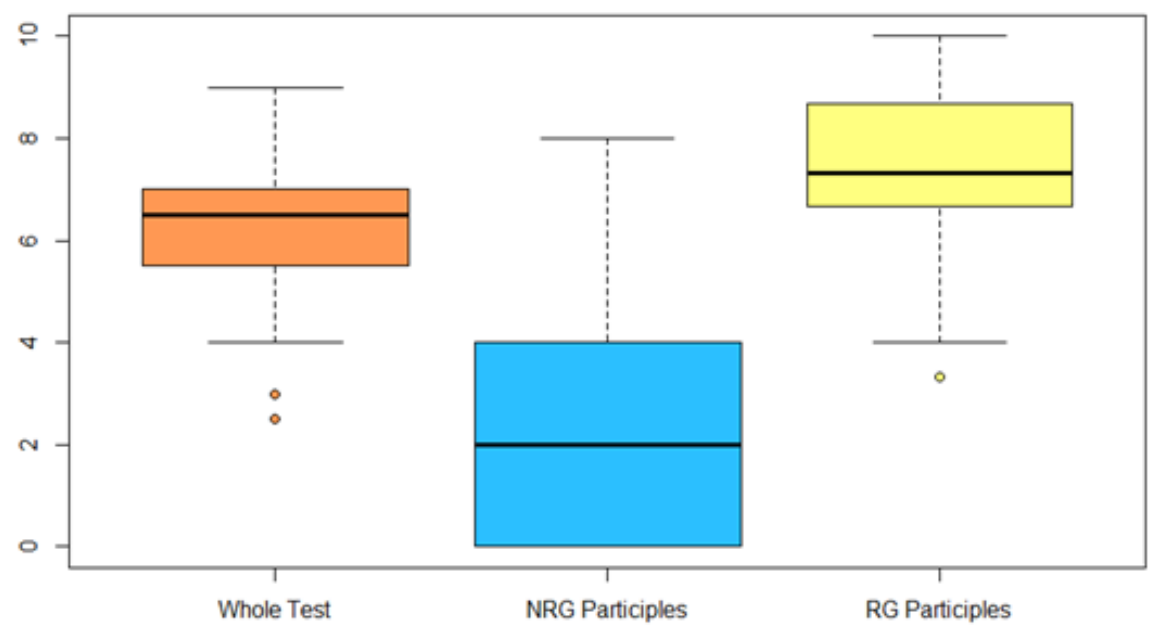

FIGURE 1

Score distributions corresponding to the entire test, NRG Participles, and RG Participles Note: NRG, non-rule-governed; RG, rule-governed Source: Own elaboration

Figure 2 presents the results of the test and the percentage of correct responses for each regular allomorph $(/ \mathrm{t} /, / \mathrm{d} /$, and $/ \# \mathrm{~d} /)$ plus the non-standard pronunciation of participial adjectives. According to Figure 2, $8.2 \%$ of the students attained the for with /\# $\mathrm{d} /$. Students scores were higher for $/ \mathrm{d} /(7.31 \%)$ than $/ \mathrm{t} /(6.49 \%)$, while the non-standard pronunciation of participial adjectivals revealed the lowest scores at $2.72 \%$.

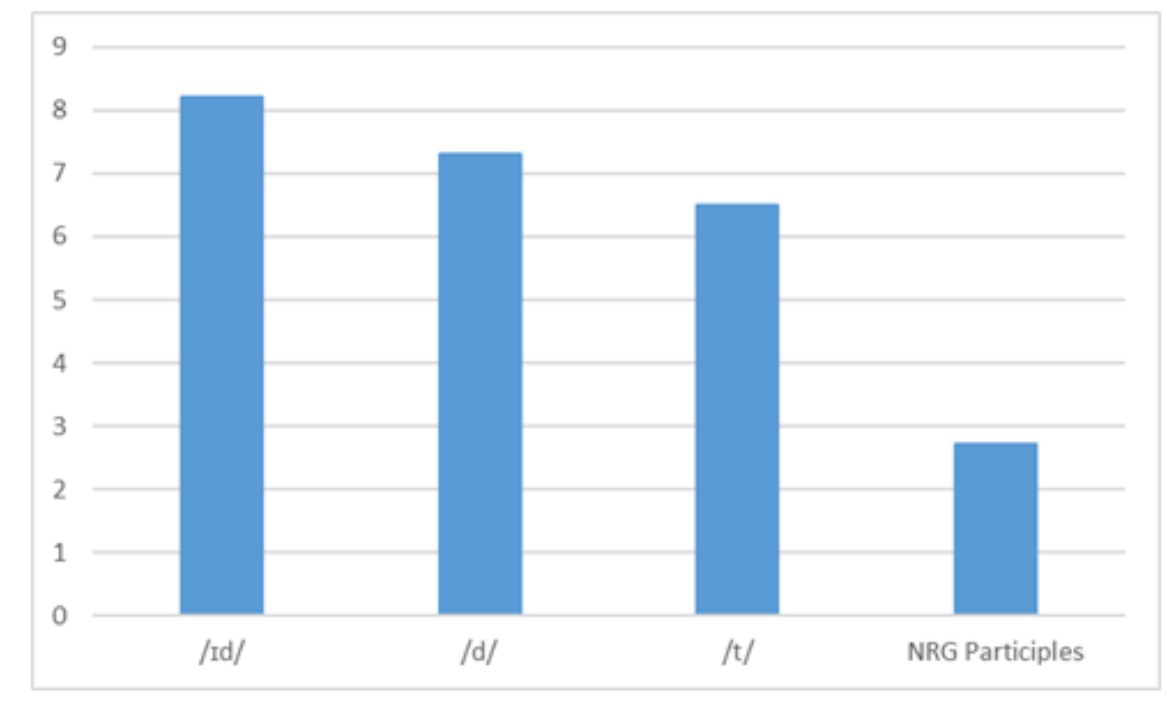

FIGURE 2

Test results by allomorph and rule variation, $\%$ correct

Note: NRG, Non-Governed Rule

Source: Elaborated by the author

Figure 3 shows the results of the test by NRG words with the percentage of correct responses for each irregular form. In general, the easiest word for students to classify was naked (42.62\%), followed by wicked $(32,79 \%)$, and wretched $(31,15 \%)$. The words that were most troublesome for students were rugged $(18,03 \%)$ and learned (6,56\%). These results reveal that more than two-thirds of the entire popluatation have trouble pronouncing NRG adjectives. 


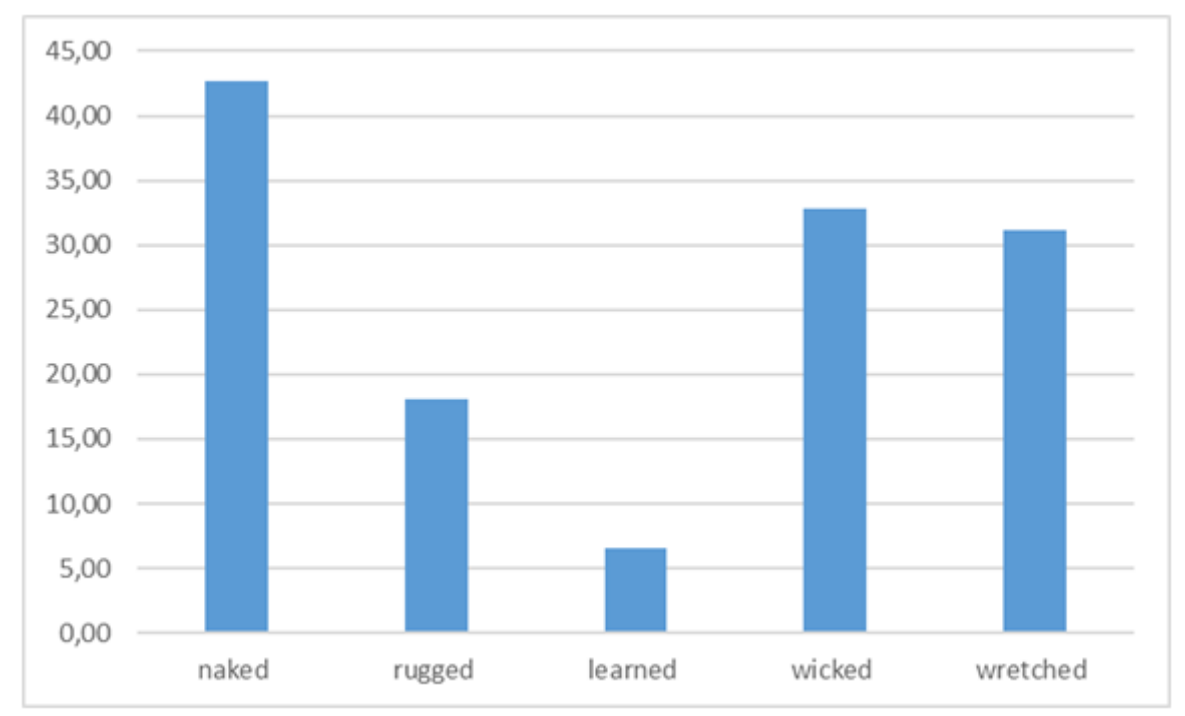

FIGURE 3

Test Results by NRG Words, \% correct

Source: Elaborated by the author

\section{Discussion}

The results of this study provide important information about students' understanding of -ed inflections when used as adjectives. This study also bridges a gap found in literature by providing evidence about students' understanding of rules and exceptions when -en participles are used as adjectives. Thus, according to the data, it is possible to recommend strategies to help EFL instructors teach pronunciation. In addition, this project may motivate new lines of research in the field of applied linguistics, and, specifically, in the area of EFL and English pronunciation. The main findings of this study are further discussed in the following paragraphs.

The test results confirm that students struggle with the pronunciation rules of -ed inflections and that, approximately, half of the students do not understand how the pronunciation system of the English language operates for -en participles. This conclusion can be generalized for the pronunciation of regular verbs in the past since the same rule applies to both cases with the exception of NRG participle rule which students tend to overgeneralize. Students tend to believe that NRG participles are pronounced as are regular verbs in the past tense. However, only a few students acknowledge that these pronunciation irregularities exist in the English language, they do not completely master them. Even when considering the results for rule-governed participles only, approximately half of the students are being left behind. Since some students may not be adept monitor users or prefer to focus on other linguistics factors, the gap may be more evident with student pronunciation, particularly due to a lack of awareness or understanding of pronunciation rules which makes a communication breakdown more likely.

Regarding problematic allomorphs for students, evidence supports research by Bassetti and Atkinson, 2015; Caballero and Rosado, 2018; Cardoso, 2018; Davila, 2013; Yaowaratana and Rungruang, 2018, that the allomorph $/ \# \mathrm{~d} /$ is easiest for students to recognize and produce. The main reason could be attributed to the obvious inclusion of the /\#/ sound, thus making pronunciation more salient for Spanish speakers since every letter in Spanish has a clear, distinct sound and vowels are never silent. For students, replacing the graphemes ed for $/ \# \mathrm{~d} /$ is more similar to the set of rules present in their L1. On the other hand, since two sounds are present instead of only, it is easier for EFL students to hear and recognize the pronunciation pattern. The rule is also simple: add /\#d/ if the last sound before the -ed inflection is $/ \mathrm{t} / \mathrm{or} / \mathrm{d} /$. 
The $/ \mathrm{t} /$ and /d/ allomorphs are more troublesome for students than the /\#d/ allomorph. Although students, generally understand the rule for the /d/ sound, results are still low for students majoring in English. The results may also be partially due to the number of instances where $/ \mathrm{d} /(\mathrm{n} \approx 25)$ is used versus / $\mathrm{t} / \mathrm{n}$ $\approx 8)$. The /\#/ and / $\mathrm{t} \# /$ combinations of the $/ \mathrm{t} /$ sound are particularly difficult for students. Voicing, as described by Richards and Schmidt (2010), may be a source of confusion for students, as well. Regarding both cases, students must understand that, despite the associated awkwardness of -ed inflections, they can be pronounced as $/ \# \mathrm{~d} /, / \mathrm{t} /$ or $/ \mathrm{d} /$ where the vowel grapheme becomes silent in speech and, therefore, remain absent in phonetic transcriptions. Students must also adjust their ingrained linguistic system to accept nonfamiliar consonant sounds in clusters at the end of words.

NGR participles ending in -ed are considered to be the most difficult for students to understand and pronounced. Whereas -ed realized as /\#d/ is an easier concept for students to grasp, NGR participles are on the opposite side of the spectrum, since they are also be pronounced as $/ \# \mathrm{~d} /$, but do not adhere to regular pronunciation rules of -ed endings. It is possible to assume that students may find them difficult for two main reasons. On one hand, NGR participles are exceptions to the rules and are taught after pronunciation rules for regular past tense verbs have been drilled for some time. Course books and professors often emphasize the pronunciation rules for the regular verbs in the past and, rather understandably, expect that students transfer those rules when pronouncing -en participles. Nevertheless, little or no attention is made to irregular patterns present in -en participles. On the other hand, there are very few participles that are exceptions to the standard rules. Additionally, some depend on contextual clues (e.g., They have one son, aged /d/ three. She takes care of her aged /\#d/ mother.), rendering the acquisition of these non-standard variations difficult for students to master.

\section{ConCLUSION}

Several authors (Brown, 2015; Hadfield and Hadfield, 2011; Harmer, 2001; Kelly, 2000; Marks and Bowen, 2012; Nation and Newton, 2009) have stated the importance of teaching rule-formation principles to students instead of expecting acquisition to happen as a result of exposure. According to Gilakjani (2011a), "Foreign language curricula emphasize pronunciation in the first year of study as it introduces the target language's alphabet and sound system, but rarely continues this focus past the introductory level" (p. 4). Thus, the following teaching recommendations can be made: Standard rules as well as the exceptions for en participles should be explicitly stated in course materials. Professors should revisit these pronunciation features (along with other pronunciation rules) throughout the course of the major and not just in one or two courses. Instructors should also design supplementary materials and follow-up activities where those pronunciation characteristics that cause more problems to students are emphasized and dealt with appropriately. Current materials should be also reviewed and modified based on student needs and require followed-up. Gilakjani (2011b) explains that "The first priority is development of a range of assessment tools to allow methods and policies to be assessed for their effectiveness" (p. 81). In terms of curricular changes, assessment of policies, methods, and procedures has not, generally, been done systematically. There are no clear procedures as to how to make such changes or who should be responsible for that. Most often, no evaluation is conducted.

Similar studies should be carried out periodically, given that research help visualize a student's language learning progress. This study also raises the possibility of other areas of research given the "...burning need for an increase in the amount of serious research at all levels into a wide range of issues to do with ESL pronunciation teaching" (Gilakjani, 2011b, p. 81). Pronunciation of plurals, homonyms, homographs, and heteronyms, along with other specific and problematic sounds, are just some of the many areas that are in urgent need of attention among EFL literature to help improve classroom practices and strategies. 


\section{REFERENCES}

Akmajian, A., Demers, R., Farmer, A., and Harnish, R. (2010). Linguistics: An Introduction to Language and Communication. United States of America: The MIT Press

Bassetti, B. and Atkinson, Nathan. (2015). Effects of orthographic forms on pronunciation in experienced instructed second language learners. Applied Psycholinguistics, 36(1), 67-91. doi: http://dx.doi.org.ezproxy.sibdi.ucr.ac.cr: 2048/10.1017/S0142716414000435

Brown, D. (2015). Teaching by principles: An interactive approach to language pedagogy. White Plains, NY: Longman.

Caballero, D. and Rosado, N. (2018). Neurolinguistic Programming and Regular Verbs Past Tense Pronunciation Teaching. English Language Teaching, 11(11), 1-18. doi: https://doi.org/10.5539/elt.v11n11p1

Cardoso, W. (2018). Learning L2 pronunciation with a text-to-speech synthesizer. In P. Taalas, J. Jalkanen, L. Bradley \& S. Thouësny (Eds), Future-proof CALL: language learning as exploration and encounters - short papers from EUROCALL 2018 (pp. 16-21). France: Research-publishing.net. doi: https://doi.org/10.14705/rpnet.2018.2 6.806

Celce-Murcia, M., Brinton, D., and Goodwin, J. (2016). Teaching Pronunciation. Cambridge: Cambridge University Press

Davila, A. M. (2013). Spanish speakers' reading production of English past tense inflectional morpheme -ed (Masters Dissertation) Southern Illinois University Carbondale, Illinois, United States of America. Retrieved from http s://search-proquest-com.ezproxy.sibdi.ucr.ac.cr/docview/1475221589? accountid=28692

Gilakjani, A. P. (2011a). A Study on the Situation of Pronunciation Instruction In ESL/EFL Classrooms. Journal of Studies in Education, 1(1) 1-15. doi: https://doi.org/10.5296/jse.v1i1.924

Gilakjani, A. P. (2011b). Why is pronunciation so difficult to learn? English Language Teaching, 4(3), 74-83.

Hadfield, J. and Hadfield, C. (2011). Oxford Basics: Introduction to Teaching English. Cambridge: Cambridge University Press.

Harmer, J. (2001). The practice of English language teaching. England: Longman.

Kelly, G. (2000). How to teach pronunciation. England: Longman.

Kolln, M., and Funk, R. (2011). Understanding English Grammar. New York: Longman.

Yaowaratana, K., and Rungruang, A. (2018). How Thai EFL Learners Deal with English Regular Past Forms: A Case Study of a Speech Sound Perspective. English Language Teaching, 11(7), 1-21.

Marks, J., and Bowen, T. (2012). The book of pronunciation: proposals for a practical pedagogy. Peaslake: Delta Publishing.

Nation, P. and Newton, J. (2009). Teaching ESL/EFL listening and speaking. New York: Routledge.

Plag, I. (2003). Word-Formation in English (Cambridge Textbooks in Linguistics). Cambridge: Cambridge University Press. doi: https://doi.org/10.1017/CBO9780511841323

Richards, J., and Schmidt, R. (2010). Longman dictionary of language teaching and applied linguistics. Oxfordshire, England: Routledge.

Roach, P. (2010). English phonetics and phonology: A practical course. Cambridge: Cambridge University Press.

Thornbury, S. (2005). How to teach speaking. England: Longman.

\section{Appendix A}

Annotated Test

Date: ID: 
I. Read the following sentences. Circle the corresponding pronunciation of the -ed ending for the underlined word in each sentence.

1. After listening to her story, I was too moved to speak.

$/ \mathrm{t} / / \mathrm{d} / / \# \mathrm{~d} /$

2. Bacteria are too small to be seen with the naked eye.

$/ \mathrm{t} / / \mathrm{d} / / \# \mathrm{~d} /$

3. El Dorado a fairly remote, rugged area.

$/ \mathrm{t} / / \mathrm{d} / / \# \mathrm{~d} /$

4. He seemed convinced after analyzing the facts.

$/ \mathrm{t} / / \mathrm{d} / / \# \mathrm{~d} /$

5. He was a learned scholar.

$/ \mathrm{t} / / \mathrm{d} / / \# \mathrm{~d} /$

6. I think you're a bit confused.

$/ \mathrm{t} / / \mathrm{d} / / \# \mathrm{~d} /$

7. I was too embarrassed to say another word.

$/ \mathrm{t} / / \mathrm{d} / / \# \mathrm{~d} /$

8. I was very touched by her humble behavior.

$/ \mathrm{t} / \mathrm{d} / \mathrm{d} / \mathrm{d} /$

9. Laura had such a wicked sense of humor.

$/ \mathrm{t} / / \mathrm{d} / / \mathrm{\# d} /$

10. Many people like to feel needed.

$/ \mathrm{t} / / \mathrm{d} / / \mathrm{\# d} /$

11. Marco was rather alarmed that they hadn't arrived.

$/ \mathrm{t} / / \mathrm{d} / /$ \#d/

12. She felt encouraged by their words.

$/ \mathrm{t} / / \mathrm{d} / / \mathrm{Ad} /$

13. She's not especially interested in cooking.

$/ \mathrm{t} / / \mathrm{d} / / \mathrm{Ad} /$

14. Sofía was sick and tired of all this routine.

$/ \mathrm{t} / / \mathrm{d} / / \# \mathrm{~d} /$

15. The children are excited about the trip.

$/ \mathrm{t} / \mathrm{d} / / \mathrm{Ad} /$

16. There is a very relaxed atmosphere between the boss and her employees.

$/ \mathrm{t} / / \mathrm{d} / / \mathrm{\# d} /$

17. They were shocked after finding out about the robbery.

$/ \mathrm{t} / / \mathrm{d} / / \# \mathrm{~d} /$

18. Under the old regime, people lived in wretched conditions.

$/ \mathrm{t} / / \mathrm{d} / / \# \mathrm{~d} /$

19. We listened fascinated as he played the piano.

$/ \mathrm{t} / / \mathrm{d} / / \# \mathrm{~d} /$

20. Which was the most downloaded app of the year?

$/ \mathrm{t} / / \mathrm{d} / / \# \mathrm{~d} /$

Note: Items 4, 7, 8, 16, and 17 contain the /t/ sound. Items 1, 6, 11, 12, and 14 are examples of the /d/ sound. Items 10, 13, 15, 19, and 20 should be answered with /\#d/. Finally, items 2, 3, 5, 9, and 18 include NRG participles and should be marked as /\#d/

CC BY-NC-ND 